\title{
MORPHOLOGICAL ALTERATIONS IN THE MASSETER MUSCLE INDUCED BY UNILATERAL EXTRACTION OF THE UPPER MOLARS IN GUINEA PIGS (Cavia porcellus)
}

\author{
ALTERACIONES MORFOLÓGICAS EN EL MÚSCULO MASETERO POR EXTRACCIÓN UNILATERAL DE LOS MOLARES \\ SUPERIORES EN COBAYAS (Cavia porcellus)
}

\author{
*João Paulo Mardegan Issa; *Mamie Mizusaki Iyomasa; *'Cristina Ioshie Mizusaki; \\ ${ }^{* * * *}$ Ii-sei Watanabe $\&{ }^{* * * * *}$ Carlos Alberto Mandarim de Lacerda
}

ISSA, M. J. P.; IYOMASA, M. M.; MIZUSAKI, C. I., WATANABE, I. \& MANDARIM-DE-LACERDA, C. A. Morphological alterations in the masseter muscle induced by unilateral extraction of the upper molars in guinea pigs (Cavia porcellus). Int. J. Morphol., 22(3):225-230, 2004.

SUMMARY: The objective of the present study was to analyze morphological aspects of the structures of the stomatognathic system and their relationship with malocclusion. For this purpose, we determined the morphological alterations that occur in the masseter muscle of guinea pigs (Cavia porcellus) after the induction of malocclusion by extraction of the left upper molars. Animals were divided into two groups (malocclusion and control group) and submitted to macroscopic, biometric and light microscopic analyses. The results showed a reduction in the width of the masseter muscle mainly in left side in the malocclusion group 60 days after unilateral extraction. Microscopically, round and polygonal muscle fibers of several diameters were observed, and altered muscle fibers with a central nucleus, degenerating fibers and macrophages were noted in more deeply fasciculi.

KEY WORDS: 1. Masseter muscle; 2. Morphology; 3. Light microscopy; 4. Muscle fibers; 5. Guinea pig.

\section{INTRODUCTION}

Among the major current concerns in dentistry are functional disorders that affect structures of the stomatognathic system, where injuries to the masticatory muscles caused by various disorders are steadily increasing (Clark et al., 1981; Close et al., 1995 and Harriman, 1996). Electromyographic studies have revealed that fatigue, discomfort and pain in the masticatory muscles are frequently associated with occlusal alterations and loss of the posterior teeth (Clark et al. and Möller et al., 1984). Muscular pain has also been related to ischemia resulting from impaired blood flow due to prolonged muscle contraction (Bakke, 1993; Clark et al., 1981; Möller et al.; Nunes et al., 1997 and Siqueira et al., 2001); however, studies regarding the specific morphological muscular alterations resulting from malocclusion are scarce. Although reports have revealed the effects of some types of occlusal alteration on masticatory muscles in experimental animals (Bani et al., 1999; Maeda et al., 1990 and Miehe et al., 1999), only few investigations regarding the morphological alterations that occur in the masseter muscle are available.
The objective of the present study was to analyze the macroscopic, biometric and light microscopic alterations in the masseter muscle of guinea pigs induced by malocclusion in order to provide a better understanding of the effects of functional disorders on the structures of the stomatognathic system.

\section{MATERIAL AND METHOD}

We studied 20 adult male guinea pigs (Cavia porcellus) weighting 400 to $500 \mathrm{~g}$, maintained at the animal house of FORP-USP under controlled temperature, with commercial ration and water available ad libitum. The animals were divided into a control group $(n=10)$ and a malocclusion group $(n=10)$, in each group were divided into two with five animals from each sub group: 1) used for macroscopic and biometric analysis and 2) used for light microscopic analysis.

* Department of Morphology, Stomatology and Physiology, Ribeirão Preto School of Dentistry, State University of São Paulo (USP), Ribeirão Preto, SP, Brazil.

** Biological Science Center, Federal University of Santa Catarina, Florianópolis, SC, Brazil.

**** Biomedical Science Institute, State University of São Paulo (USP), São Paulo, SP, Brazil.

${ }^{* * * * *}$ Department of Morphology, Medical Center, State University of Rio de Janeiro, RJ, Brazil. 
Induction of malocclusion. In the malocclusion group, each animal was anesthetized with tribromoethanol $(0.25 \mathrm{~g} / \mathrm{kg}$ body weight) and submitted to extraction of the upper molars in the left hemiarch, with animals receiving the antibiotic benzathine benzylpenicillin (benzetacyl, 200,000 IU) as preoperative prophylaxis. After asepsis and disinfection of the surgical site with merthiolate, extraction was performed with anatomical tweezers and Hollemback $3 \mathrm{~s}$. The extraction area was compressed to stop bleeding (Chompret maneuver). After surgery, the animals received anti-inflammatory and analgesic drugs (sodium diclofenac) and were maintained in appropriate cages for two months. Animals from the malocclusion group received pelleted ration and cabbage leaves during the first week. After this period, they were fed the same diet as used for control animals, i.e., ration and water ad libitum, daily cabbage complement, and grass three times a week. Animal handling followed the requirements of the Ethics Committee on the Use of Animals in Experimentation.

A - Specimen preparation for macroscopic and biometric analysis. After two months, guinea pigs from the malocclusion and control groups were anesthetized with urethane $(0.4 \mathrm{ml} / 100 \mathrm{~g}$ body weight $)$ and injected intracardially with $7 \%$ of body weight $0.9 \%$ physiological saline to wash the vessels, followed by perfusion with the same amount of $10 \%$ formalin in sodium phosphate buffer, $\mathrm{pH}$ 7.4. The animals were kept immersed in the fixative for later dissection and macroscopic and biometric analysis. The statistical analysis of biometric data were made using the paired and no-paired test-t student.

B - Specimen preparation for microscopic morphological analysis. The animals were treated as described above until the perfusion step with $10 \%$ formalin in sodium phosphate buffer, $\mathrm{pH}$ 7.4. The masseter muscles were then removed and immersed in the same fixative. After fixation, the specimens were submitted to routine processing, embedded in paraffin and cut into 6- $\mu \mathrm{m}$ thick sections in the frontal direction. The sections were stained with hematoxylin-eosin, analyzed under a light microscope and photographed using a photomicroscope.

\section{RESULTS}

Morphological macroscopic and biometric results. The major axis of the guinea pig masseter muscle showed an anteroposterior orientation and the fibers of the superficial bundle were arranged antero-posteriorly (Fig.1). The superficial bundle originated anteriorly at the root of the zygomatic process of the maxilla through a strong cylindroid tendon and was inserted by expanded manner on the lateral side in the posterior half of the deep bundle above an aponeurosis, and in the postero-inferior region of the mandible ramus of the medial side. Its inferior region inserted above the crest of the posterior process of mandible ramus where its fibers intercrossed with the medial pterygoid muscle. Biometric analysis revealed the mean values as the following table.

Table I. The mean of the length and width masseter muscle on left and right sides of control and treated animals.

\begin{tabular}{cll}
\hline Length of muscle & Mean & Std Dev \\
CR & 42.28 & 1.126 \\
CL & 42.26 & 0.7299 \\
TR & 42.64 & 0.708 \\
TL & 42.98 & 0.9654 \\
Width of muscle & & \\
CR & 24.22 & 1.894 \\
CL & 24.62 & 1.359 \\
TR & 22.14 & 1.216 \\
TL & 22.72 & 1.139 \\
\hline
\end{tabular}

The width of the treated animal muscle, on left side, was significatly slight than the left side of control group $(\mathrm{p}=0.04)$.

Table II. Width mean of right and left masseter muscle in control an treated animal by student test-t (not paired).

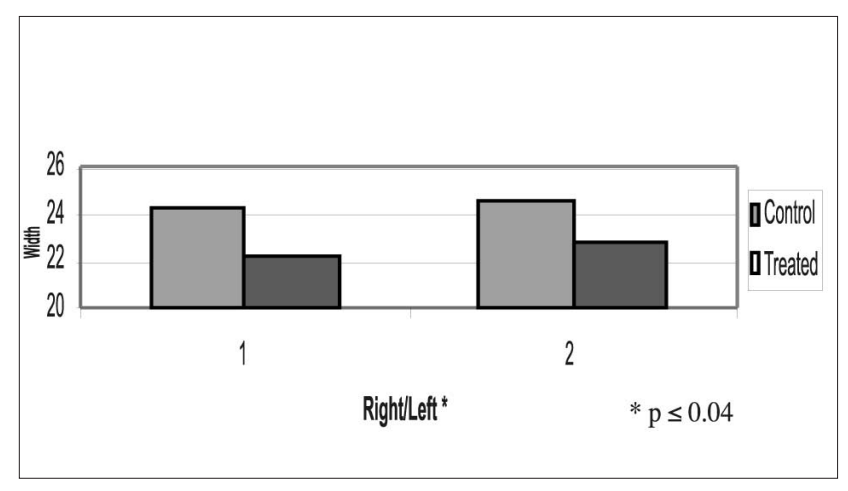

Morphological microscopic results. In the control group, the superficial bundle of the guinea pig masseter muscle showed a strong tendon anteriorly inserted into the lower part of the root of the zygomatic process of the maxilla. This tendon was thickened in the inferomedial portion and had the shape of a superficial aponeurosis in the anterior portion of the muscle belly. The posterior half of the muscle presented thick septae of dense connective tissue, which did not completely separate the muscle into real bundles, thus characterizing a multipennate muscle. Few muscle spindles were identified in the muscle belly of the superficial bundle, one of them fused. In the upper deep portion, a fasciculus clearly separated by loose connective tissue revealed various spindles, some fused and others not. 


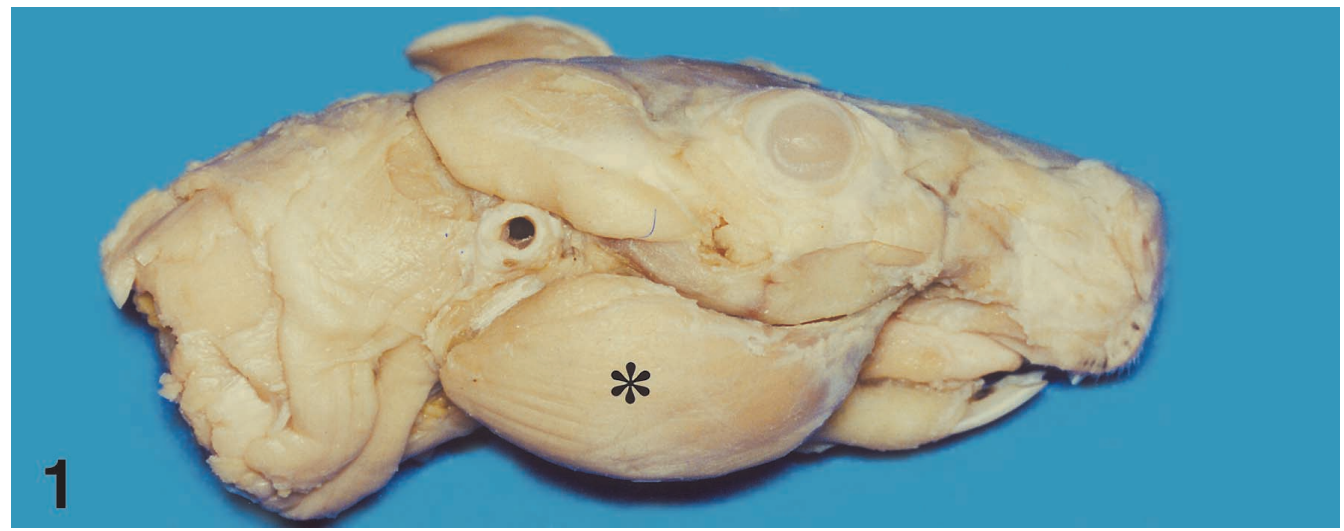

Fig. 1. Lateral view of the guinea-pig Cavia porcellus. It evidences the masseter muscle $(*)$ located inferiorly to the zygomatic bone and anteroinferiorly to the acoustic meatus.
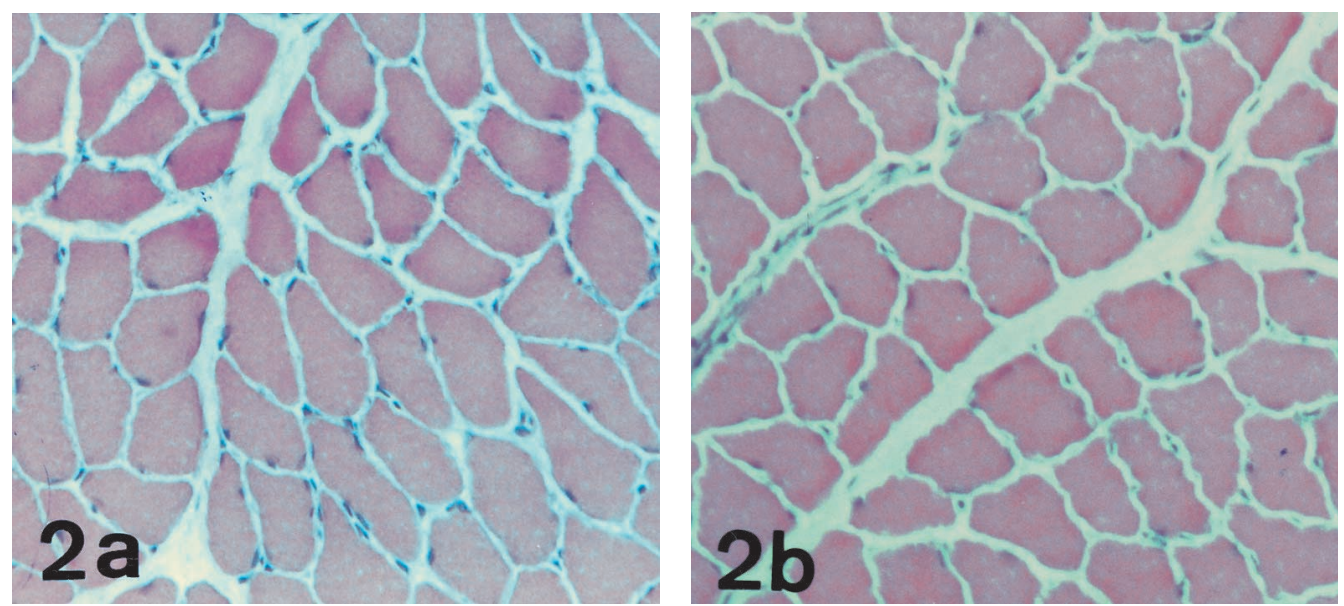

Fig. 2a. Transverse section of the right masseter muscle supercial area of control group. It shows polygonal muscle fibers constituting, in your majority. Fig. 2b. Transverse section of the left masseter muscle superficial area of control group. It evidences polygonal muscular fibers and the blood vessels of the endomysium.
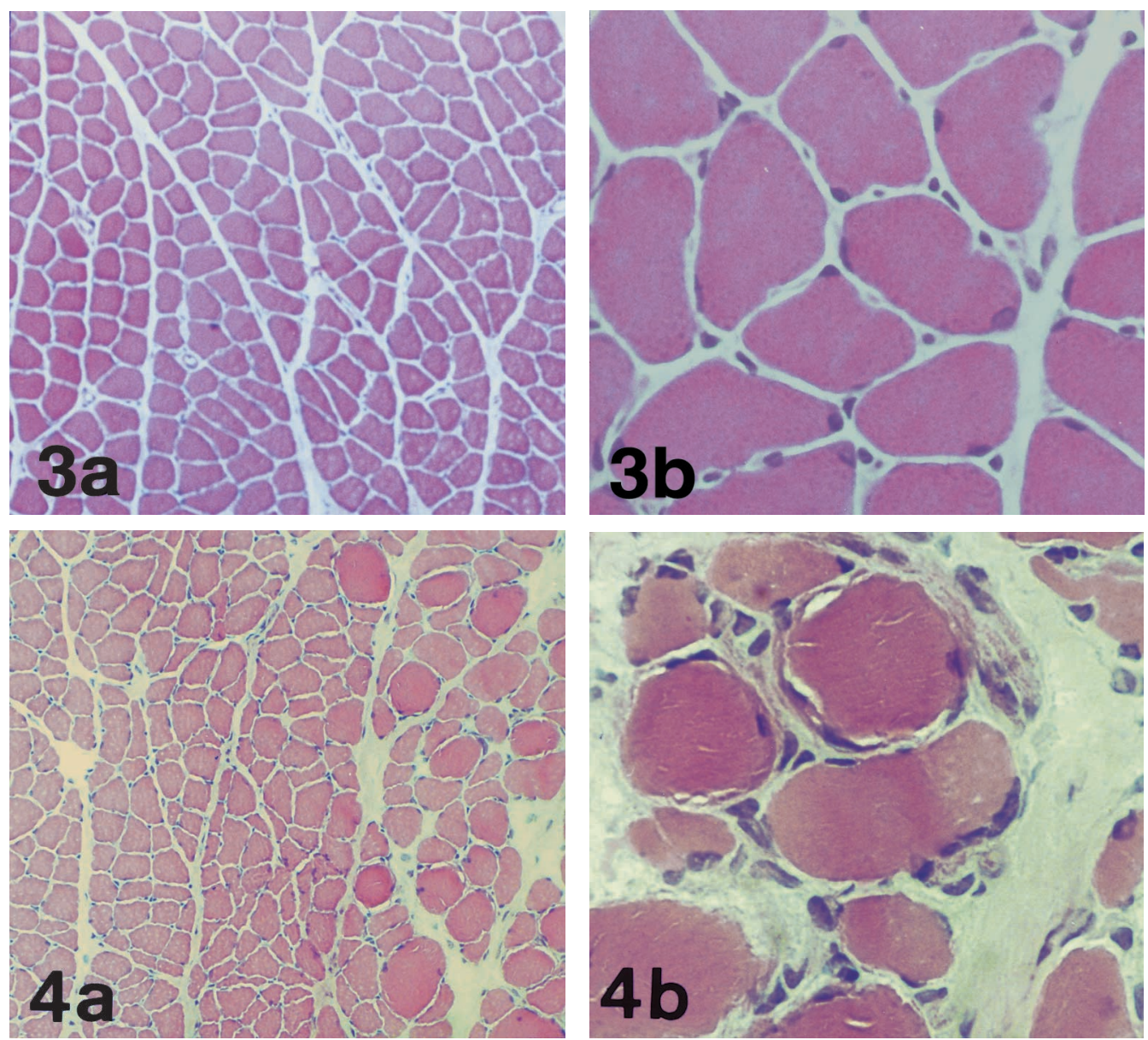

Fig. 3a. A general view of transverse section of the right masseter muscle superficial area of the treated group. Fig. 3b. A high magnification of anterior view showing the muscles fibers similar to control group.

Fig. 4a. A general view of transverse section of the left masseter muscle superficial area of treated group, showing some altered fibers. Fig. 4b. A high magnification of anterior view showing the altered muscle fibers of treated group. 
The masseter muscle of control animals showed polygonal muscle fibers comprising fasciculi in the superficial region of the muscle (Fig. 2a) and an endomysium rich in blood vessels. No difference was observed between the right (Fig. 2a) and left side (Fig. 2b).

In the malocclusion group, the masseter muscle on the right side showed polygonal and round muscle fibers present in the fasciculi of the superficial region. Despite this difference in shape, the fiber diameter was similar in the control and malocclusion groups (Fig. 3a and 3b). In contrast, on the left side, although the fasciculi in the superficial region were similar to those of the control group, altered fibers containing a central nucleus, degenerating fibers (Figs. 4a e 4b) were observed deep in the masseter muscle of experimental animals (Fig. 4a), and round fibers of variable diameters were more clearly visible.

\section{DISCUSSION}

The present macroscopic analysis revealed an irregular lozenge-like morphology of the guinea pig masseter muscle, with the superficial fibers being arranged in an anteroposterior direction. The superficial bundle resembled that of rats (Greene, 1959), and was partially separated from the deeper bundles by thick septae of connective tissue, as also observed by Rowlerson et al. (1988).

Despite morphological differences between the human and guinea pig masseter muscle, especially in terms of fiber arrangement in the superficial bundle, some common characteristics have been described in the classic literature, such as the tendinous aponeurosis lining up to one third of the masseter muscle as well as the tendinous plates alternating with muscle bundles which create a highly complex intimate structure (multipennate). These characteristics promote a reduction in the length of the contractile elements at the same time as the number of muscle fibers increases. Fiber length and arrangement (multipennate) and the large amount of tendinous tissue characterize the guinea pig masseter muscle as a potent muscle, confirming human studies (Sato et al., 1992 and Van Eijden et al., 1997) which showed that the architectural characteristics of the masseter are adequate for force production.

The biometric data obtained after malocclusion revealed a significant decrease in the width, of the masseter muscle on the left side compared to the control group. These reduced biometric values suggest functional alterations induced by malocclusion. Diet consistency influences the development of the masticatory system, with a solid diet leading to an increase in the weight of the mandibular bone and masseter muscle (Kuboyama \& Moriya, 1995), while animals receiving a liquid or soft diet show a decrease in masseter muscle weight (Ciochon et al., 1997; Maeda et al. and Miehe et al.). These data demonstrate changes in the muscle in response to stimuli, i.e., hypertrophy and atrophy due to disuse. In the present study, the reduced thickness of the masseter muscle observed in the malocclusion group indicates atrophy of some bundles due to disuse induced by tooth extraction. The absence of a change in muscle length between the malocclusion and control groups suggests that the function of the superficial bundle was not altered by this type of induced malocclusion due to the anteroposterior orientation of its fibers.

Microscopic analysis of the masseter muscle on the side of the extraction showed round fibers of variable diameters, large quantities of altered fibers and the presence of macrophages, especially in the deep bundle. The superficial bundle of both the ipsilateral and contralateral muscles of experimental animals did not show significant alterations compared to the control group. Maeda et al. reported that a liquid diet and unilateral extraction cause a reduction in the diameter of extrafusal, and later intrafusal, fibers. The similar microscopic characteristics observed for muscles from the right side of experimental animals, i.e., the side not submitted to extraction, and for muscles obtained from both sides of control animals confirm findings showing that the sensory stimuli of the periodontal ligament play an important role in maintaining masseter muscle homeostasis (Bani et al.).

The present study permits us to conclude that the reflexes of malocclusion are installed 60 days after induction of malocclusion by unilateral tooth extraction. Macroscopic and biometric analysis revealed 1) a reduction in the thickness and width of the masseter muscle of surgically treated animals compared to the control group on the left side (hipofunction), 2) no significant difference in muscle length between the malocclusion and control groups.

Microscopic analysis yielded the following findings: 1) both in the malocclusion and control groups, the two posterior thirds of the masseter muscle consist of alternating muscle bundles and thick septae of connective tissue; 2) in the control group, a similar arrangement of polygonal muscle fibers in the fasciculi of superficial region was observed on the right and left side and; 3) in the malocclusion group, a large amount of morphologically altered fibers of variable diameters were observed in the deep bundle on the ipsilateral side, with these changes being more discrete on the contralateral side, while the superficial bundle presented characteristics similar to the control group.

ACKNOWLEDGMENTS: This study was supported by FAPESP (No. 01/01142-6). 
ISSA, M. J. P.; IYOMASA, M. M.; MIZUSAKI, C. I., WATANABE, I. \& MANDARIM-DE-LACERDA, C. A. Alteraciones morfológicas en el músculo masetero por extracción unilateral de los molares superiores en cobayas (Cavia porcellus). Int. J. Morphol., 22(3):225-230, 2004.

RESUMEN: El objetivo del presente estudio fue analizar los aspectos morfológicos del sistema estomatognático y su relación con la mala oclusión. Con tal propósito, determinamos las alteraciones morfológicas que ocurren en el músculo masetero de cobayas, Cavia porcellus después de la inducción de mala oclusión a través de la extracción de los molares superiores del lado izquierdo. Los animales $(\mathrm{n}=20)$ fueron divididos en dos grupos (control y experimental), los cuales fueron sometidos a análisis biométricos, angioarquitecturales macroscópicos y al microscopio de luz. Los resultados obtenidos permitieron concluir que, después de 60 días de extracción dental unilateral hubo reducción en el ancho y en el grosor del músculo masetero del grupo experimental. Microscópicamente, se observaron fibras musculares de variados diámetros, de forma redondeada y poligonal, fibras musculares alteradas con un núcleo central, además de fibras en degeneración y macrófagos evidentes en la parte profunda del músculo.

PALABRAS CLAVE: 1. Músculo masetero; 2. Morfología; 3. Microscopio de luz; 4. Fibras musculares; 5. Cobayas.

\section{REFERENCES}

Bakke, M. Mandibular elevator muscles: physiology, action, and effect of dental occlusion. Scand. J. Dent. Res., 101:314-31, 1993.

Bani, D.; Bani, T. \& Bergamini, M. Morphologic and biochemical changes of the masseter muscles induced by occlusal wear: studies in a rat model. J. Dent. Res., 78(11):1735-44, 1999.

Ciochon, R. L.; Nisbett, R. A. \& Corrucini, R. S. Dietary consistency and craniofacial development related to masticatory function in minipigs. J. Craniofac. Genet. Dev. Biol., 17(2):96-102, 1997.

Clark, G. T.; Beemsterbeer, P. L. \& Rugh, D.G. Nocturnal masseter muscle activity and symptoms of masticatory disfunction. J. Oral. Rehabilit., 8:279-86, 1981.

Close, P. J.; Strokes, M. J.; L`Estrance, P. R. \& Rowell, J. Ultrasonography of masseter muscle size in normal adults. J. Oral. Rehabilit., 22(2):129-34, 1995.

Greene, E. C. Anatomy of the rat. New Series- Vol. XXVII, Hafner Publishing Co., New York, 1959.

Harriman, D. G. The histochemistry of reactive masticatory muscles hypertrophy. Muscle \& Nerve, 19(11):144756, 1996.

Kuboyama, \& Moriya, Y. Influence of diet composition and malocclusion on masticatory organs in rats. $J$. Nihon. Univ. Sch. Dent. Jun; 37(2): 91-6. 1995.

Maeda, N.;Suwa. I.; Ichikawa, M.; Masuda, T. \& Kumegawa, M. Effects of easily chewable diet and uni- lateral extraction of upper molars in the masseter muscle in developing mice. Acta Anat., 137:19-24, 1990.

Miehe, B.; Fanghanel, J.; Kubein-Meesenburg, D.; Nägerl, H. \& Schwestkapolly, R. Masticatory musculature under altered occlusal relationships- a model study with experimental animals. Ann. Anat., 181: 37-40, 1999.

Möller, E.; Sheikholeslam, A. \& Lous, I. Response of elevator activity during mastication to treatment of functional disorders. Scand. J. Dent. Res., 92:64-83, 1984.

Nishide, N.; Baba, S.; Horin, N. \& Nishigawa, H. Histological study of rat masseter muscle following experimental occlusal alteration. J.Oral. Rehabil., 28, 294-8, 2001.

Nunes, L. J.; Silva, M. A. M. R.; Bataglion, C.; Mazzeto, M. O.; Centola, A. L. B.; Nascimento, T. N. \& Vinha, D. Oclusão, enceramento e escultura dental. Pancast, São Paulo, 1997.

Palk, C. H.; Satomi, I. M.; Saeki, Y.; Yanagisawa, K. \& Kuwahara, Y. Increase in vertical dimension alters mechanical properties and isometric ATPase activity in guinea-pig masseter. Am. J. Orthod. Dentofac. Orthop., 104:484-91, 1993.

Rowlerson, A.; Mascarello, F.; Barker, D. \& Saed, H. Muscle-spindle distribution in relation to the fibre-type composition of masseter in mammals. J. Anat., 161: 37-60, 1988. 
ISSA, M. J. P.; IYOMASA, M. M.; MIZUSAKI, C. I., WATANABE, I. \& MANDARIM-DE-LACERDA, C. A.

Sato, I.;Shimada, K.; Ezure, H. \& Sato, T. Analysis of the tendinous structure in human masticatory muscles. Acta Anat., 143:205-10, 1992.

Siqueira, J. T. T. \& Teixeira, M. J. Dor Orofacial - Diagnóstico, Terapêutica e Qualidade de Vida, 2001.

Van Eijden, T. M. G. J.; Korfage, J. A. M. \& Brugman, P. Architecture of the human jaw-closing and jaw-opening muscles. Anat. Rec., 248:464-74, 1997.
Correspondence to:

Prof. Dra. Mamie Mizusaki Iyomasa

Departamento $\mathcal{M E F}$,

Faculdade de Odontologia de Ribeirão Preto,

Universidade de São Paulo (USP)

Av. Cafe $s / n$

CEP: $14040-904$

Ribeirão Preto, $S P$

BRASIL

E-mail:mamieiyo@forp.usp.br.

Received : 22-06-2004

Accepted : 25-07-2004 